\title{
Strength of Glass Fiber Reinforced Plastics
}

\author{
by
}

\section{Taichi FujII}

(Faculty of Engineering, Osaka Gity University, Osaka)

As widely known, glass fiber reinforced plastics have very great value of strength weight ratio and many other excellent properties, being heat and water proof and having electric resistance among others. Hence glass fiber reinforced plastics are attracting the attention of the engineering world. The investigation about the strength of glass reinforced plastics is performed by many researchers from different standpoints, the summarizing consideration there of being required by many engineers. The present paper proposes to give such summarizing considerations about the strength of glass fiber reinforced plastics to meet the above mentioned requirement. (Received Feb. 11, 1965)

\section{1 緒言}

強化プラスチックスは広い意味では強化処理をされ たプラスチックス全部を指すものと考光られるが，わ れわれが普通強化プラスチックスと呼んでいるものは， ガラス繊維をもって補強されたプラスチックスを意味 する場合が多く， Glass fiber reinforced plastics あ るいは略して FRP と呼んでいる，FRP の強度特性
を金属材料と比較してまず気づくてとは強度〜重量比 が著しく大きいてとである。すなわち Table I 亿見 られるように朱子織ガラスクロスを用いた FRP（ガ ラス重量含有率 $\beta=60 \%$ ，樹脂はポリエステル）の引 張強度は $33 \mathrm{~kg} / \mathrm{mm}^{2}$ で構造用炭素鋼に迫り, 引張強度 ～比重比は 3 倍以上になっている，また，その強度は 補強材であるガラス繊維の含有率によって大きく変わ

Table I. Comparison of mechanical properties of FRP and other materials.

\begin{tabular}{|c|c|c|c|c|c|c|c|c|}
\hline Materıal & $\begin{array}{c}\text { Tensil } \\
\text { strength } \\
\left(\mathrm{kg} / \mathrm{mm}^{2}\right)\end{array}$ & $\begin{array}{l}\text { Young's } \\
\text { modulus } \\
\left(\mathrm{kg} / \mathrm{mm}^{2}\right)\end{array}$ & $\begin{array}{l}\text { Compression } \\
\text { strength } \\
\left(\mathrm{kg} / \mathrm{mm}^{2}\right)\end{array}$ & $\begin{array}{c}\text { Bendıng } \\
\text { strength } \\
\left(\mathrm{kg} / \mathrm{mm}^{2}\right)\end{array}$ & $\begin{array}{c}\text { Shear } \\
\text { strength } \\
\left(\mathrm{kg} / \mathrm{mm}^{2}\right)\end{array}$ & $\begin{array}{c}\text { Impact value } \\
\text { (Charpy) } \\
\left(\mathrm{kg}-\mathrm{cm} / \mathrm{cm}^{2}\right)\end{array}$ & $\begin{array}{l}\text { Specıfic } \\
\text { weight }\end{array}$ & $\begin{array}{c}\text { Tensıle } \\
\text { strength } \\
\text { Specific } \\
\text { weıght }\end{array}$ \\
\hline $\begin{array}{l}\text { FRP } \beta=60 \% \\
\left(\begin{array}{l}\text { Satin wooven } \\
\text { glass cloth }\end{array}\right)\end{array}$ & 33 & 2200 & 28 & 50 & $11 \sim 14$ & 130 & 1.8 & 18.3 \\
\hline $\begin{array}{l}\text { FRP } \beta=50 \% \\
\text { (Robing glass cloth) }\end{array}$ & 26 & 2000 & 18.4 & 30 & 16.3 & 220 & 1.7 & 15.3 \\
\hline $\begin{array}{l}\text { FRP } \beta=30 \% \\
\left(\begin{array}{l}\text { Plane woven } \\
\text { glass cloth }\end{array}\right)\end{array}$ & 26 & 1600 & 24.3 & 30 & 10 & 100 & 1.7 & 15.3 \\
\hline $\begin{array}{l}\text { FRP } \beta=30 \% \\
\text { Mat }\end{array}$ & 10 & 1000 & $23 \quad 27$ & $14 \quad 18$ & $8-10$ & 100 & 1.6 & 6.25 \\
\hline Carbon steel SS-41 & 42 & 21000 & - & - & - & 1500 & 7.8 & 5.39 \\
\hline $\begin{array}{l}\text { Aluminium alloy } \\
24 S-T\end{array}$ & 47 & 7000 & - & - & 28 & $260 \sim 290$ & 2.8 & 16.2 \\
\hline $\begin{array}{l}\text { Aluminium alloy } \\
52 \mathrm{~S}-\mathrm{O}\end{array}$ & 19 & 7000 & - & - & 12.7 & 830 & 2.8 & 6.78 \\
\hline Polyester & 4.1 & 380 & 15.8 & 11.5 & 6.6 & 1.1 & 1.1 & 3.72 \\
\hline Vınyl & 6.0 & 300 & 10 & 10 & 40 & 3.0 & 1.4 & 4.28 \\
\hline Metacrile resın & 7.2 & 280 & 10 & 10 & 4.4 & 3.0 & 1.4 & 5.13 \\
\hline
\end{tabular}


るので，目的によって適当な強度のものを選択するて とができるのも特徵と思われる. 以上のほか電気絶縁 性，耐食性もすぐれているので，乙れらの性質を生か して, 各方面に広く用いられつつあるととは周知のと てろであろう.

さて，補強材料として用いられるガラス繊維はガラ スフィラメントのままで用いられる場合もあるが，普 通朱子織, 平織等の布にして用いられている。 また, 繊維をある長さに切断しマット状にしたもの, 繊維を 多数たばねて幅の広い繊維束いわゆるロープを形成し, これにより布を織ったもの（ロービング布）を用いら れている。 なお, 補強材としてビニロン布, あるいは 金属線条が用いられる場合もある。

さて，強化プラスチックスが基材と補強材とによっ て構成された複合体であるてとを考えると，その強度 特性は基材と複合体それぞれの特性とかなり異なった ものとなるととが予想される，したがって，強化プラ スチックスの強度特性を決定する要因として種々のも のが考光られているが，そのおもなものをあげると，

（a）樹脂(基材) と補強材それぞれの強度特性

(b) 補強材の含有率

(c) 成形方法, 条件等

（d）作用する負荷の種類, 負荷条件 等である.

\section{2 静 的 強 度}

強化プラスチックスの構成材料は前項に述べたよう にガラス纎維クロス, 樹脂であるが, 強度を要求され る場合に広く用いられているものとして，朱子織ガラ スクロスポリエステル（またはエポキシ）の積層材

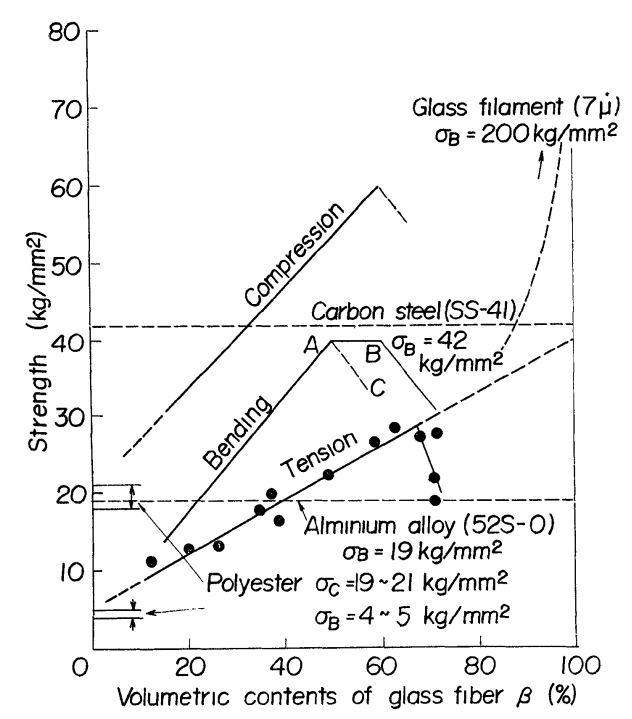

Fig. 1. Static strength of glass-clothpolyester FRP.
があげられる．Fig.1はポリエステル，朱子織ガラス クロスの静的強度をまとめたもので, ガラス繊維容積 含有率を横軸に，縦軸に破猿応力をとれば，眓から認 められるように，体積含有率で約 $60 \%$ まで，強度が増 加しているととがわかる. 引張強度は, 積層面に沿う 方向, 補強材の主方向に引張った場合で, 含有率零, すなわちポリエステルの引張強度を基点としてほぼ直 線的に強度が増加し，含有率が $60 \%$ を越えると急激な 強度低下を示している，てれは $60 \%$ 以上の成形は実際 問題として困難であり，FRP 内部に成形による損傷 が生ずるためと思われる。しかし，含有率に関して強 度が増大していく傾向を延長すると後述する曲げ飽和 強度に近づくようである．次に図に示された曲げ強度 は A〜B の傾向をたどる曲げ軸が積層面に平行な場 合と，A〜C の傾向を示す曲げ軸が積層面に直角な場 合とに分けることができる，前者の傾向は補強クロス がはほ単純引張りに近い状態となると思われるので, クロスの強度を示唆しているものと思われる.ガラス 瀻維のみの強度は約 $200 \mathrm{~kg} / \mathrm{mm}^{2}$ であるからろクス としたてとによる強度低下は非常に大きく，約 $1 / 5$ と なる，圧縮強度は積首面に直角な方向に圧縮した場合 を示した、積層面に平行な方向に圧縮した場合はその 強度は約 $23 \mathrm{~kg} / \mathrm{mm}^{2}$ でガラス含有率による強度増加 は認められない，ガラス繊維含有率は実際には重量含 有率で示される場合が多いが，強度特性を表わすため には容積含有率で示したほうが直線的傾向がよく表わ される。，せん断強度については資料が少ないので, その傾向をはっきり示すてとができないが，積層面に 平行にせん断を与えた場合は樹脂のせん断抵抗が主体 となると思われる。綾織ガラスクロス，ポリエステル FRP（ガラス瀻維重量含有率，62\%）に対する実験の 結果によれば

\footnotetext{
*1 ガラス絽維の強度について ガラス織維は細いほど強度が大となるととが知られていて， 近仪的に次式で強度を求めている. $\sigma_{B} \doteqdot 1500 / a \mathrm{~kg} / \mathrm{mm}^{2}$

ただし $d ;$ ガラス緉維の直径 (ミクロン)

ガラス蟣維の直径は 50〜100 本程度束にしてストラントにす るあのは 5 - 10ミクロンであるが, 長いフィラメントとして用 いるあのには, 10〜20ミクロンのあのあ用いられる、なお, ガ ラスの材料によってもその強度が変わるととはいうまであない. たとえば

無アルカリガラス䋳維 $(\boldsymbol{E}$ ガラス) 国産品 $\sigma_{B}=350 \mathrm{~kg} / \mathrm{mm}^{2}, E=7400 \sim 7700 \mathrm{~kg} / \mathrm{mm}^{2}$

米国の Owens-Corning Fiberglass 社の

Low alkali magnesıa alumina silicate glass $\sigma_{B}=455 \mathrm{~kg} / \mathrm{mm}^{2}, E=8400 \sim 8800 \mathrm{~kg} / \mathrm{mm}^{2}$

*2 ガラス䋳維重量含有率 $\alpha$ と体積含有率 $\beta$ の関係 $\beta=\alpha \frac{\rho_{F}}{\rho g}$

ただし $\rho_{F} ;$ 強化プラスチックスの比重 $\rho g ;$ ガラス繊維の比重 $\rho F$ は次式て計算される。 $\rho_{F}=\left(\rho g-\rho_{r}\right) \beta+\rho_{r}$ $\rho_{r} ; \mathrm{FRP}$ 中の硬化した樹脂の比重
} 
積層面に平行方向のせん断強度 $3.5 \mathrm{~kg} / \mathrm{mm}^{2}$ （積層面間せん断）

同上（積風面内せん断）

$6.4 \mathrm{~kg} / \mathrm{mm}^{2}$

であることが報告されている。

\section{3 強化プラスチックスの静的破壊機構}

ガラスクロス，ポリエステル FRP の引張試験を行 なうとその荷重と変形の関係はほぼ直線的であり顕著 な降伏現象を示さず破壊に至っている。しかし，少し 詳しく観察すると途中に折点のあるととが認められる. Fig. 2 は前述のせん断試験に用いられたものと同一の 材料について引張試験を行なった結果である，てのよ うな結果を説明するために種々の考察が行なわれてい るが，それらのうちで最も簡単な考え方は Fig. 3 に示 すように荷重 $P$ が作用しだときの見かけの応力を $\sigma$, 補強材の分担荷重および応力を $P_{g}, \sigma_{g}$, 樹脂の分担荷 重および応力を $P_{r}, \sigma_{r}$ とし樹脂層とガラス繊維層と を別個に考えて，両者の変形か㩐しくなるように，分 担荷重を受け持つと考える。したがって

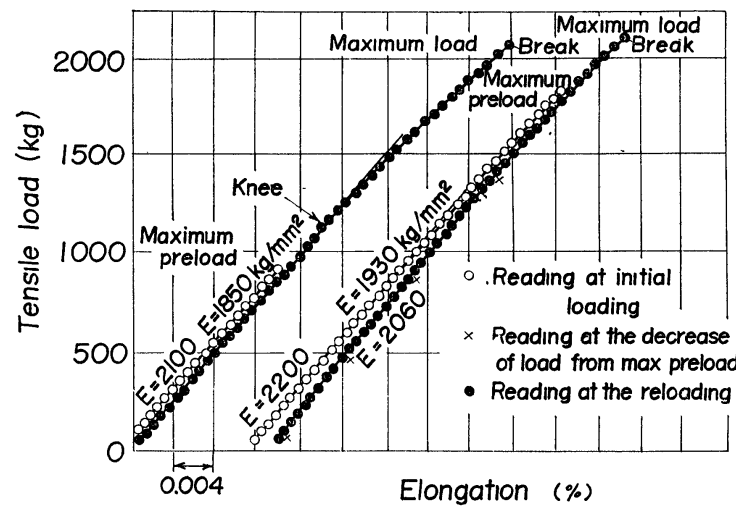

Fig. 2. Load-deflection diagram of FRP (Glases cloth-polyester FRP).

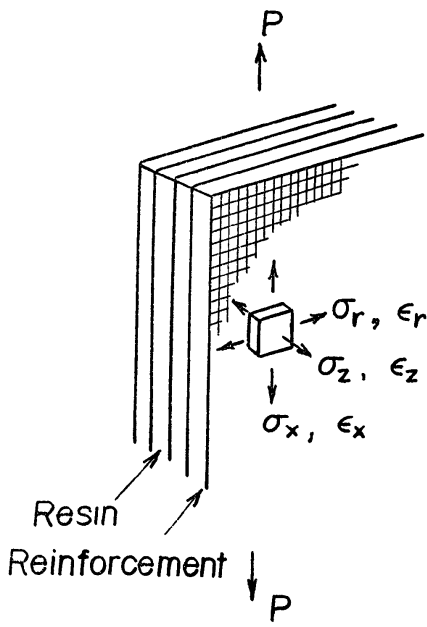

Fig. 3. Mechanical model of FRP.

$$
\sigma F=\sigma_{r} F_{r}+\sigma_{g} F_{g}
$$

ただし， $F$ は断面積，ガラス繊維体積含有率を $\beta$ と すると

したがって

$$
\beta=F_{g} / F
$$

$$
\sigma=\sigma_{r}(1-\beta)+\sigma_{g} \beta
$$

見かけの応力と分担応力の比を求めてみると

$$
\begin{aligned}
& \frac{\sigma}{\sigma_{g}}=\beta+(1-\beta) \frac{\sigma_{r}}{\sigma_{g}}=\beta+(1-\beta) \frac{E_{r}}{E_{g}} \\
& \frac{\sigma}{\sigma_{r}}=(1-\beta)+\beta \frac{\sigma_{g}}{\sigma_{r}}=(1-\beta)+\beta \frac{F_{g}}{F_{r}}
\end{aligned}
$$

となる。だし， $E_{r}, E_{p}$ はそれぞれ樹脂層，ガラス 繊維風の弾性係数である.

補強材と樹脂の強度をそれぞれ $\sigma_{g *}, \sigma_{r *}$ としその 比を $n$ とすると

$$
n \frac{\sigma_{g}}{\sigma_{g *}}\left\{\beta+(1-\beta) \frac{E_{r}}{E_{g}}\right\}=\frac{\sigma_{r}}{\sigma_{r *}}\left\{(1-\beta)+\beta-\frac{E_{g}}{E_{r}}\right\}
$$

いま，樹脂の部分がさきに破壊したとすると

$$
\sigma_{r} / \sigma_{r *}=1.0
$$

したがって

$$
\sigma_{g} / \sigma_{g_{*}}=(1 / n) E_{g} / E_{r}
$$

この值が 1 亿等しければ樹脂と補強仏は同時に破壊し 1より大であれば補強材のほうがさきに破壊すること になる。

樹脂部が破壊するときの見かけの応力と $\sigma_{g *}$ との比 を求めると

$$
\left(\frac{\sigma}{\sigma_{g *}}\right)_{1}=\frac{1}{n}\left\{\beta \frac{E_{g}}{E_{r}}+(1-\beta)\right\}=\frac{1}{n} \frac{E_{g}}{E_{r}} \beta
$$

全体が破壊するとき

$$
\left(\frac{\sigma}{\sigma_{g *}}\right)_{2}=\beta
$$

樹脂と補強仏が同時に破壊するとき

$$
\left(\frac{\sigma}{\sigma_{g *}}\right)_{2}=\beta+\frac{1-\beta}{n}
$$

補強材がさきに破壊するとき

$$
\begin{gathered}
\left(\frac{\sigma}{\sigma_{g *}}\right)_{1}=\beta+(1-\beta) \frac{E_{r}}{E_{g}} \\
\left(\frac{\sigma}{\sigma_{g *}}\right)_{2}=\frac{1-\beta}{n}
\end{gathered}
$$

Fig.4 は以上の関係を定性的に示したものである，以 上の取り扱いにおいては，たとえば樹脂層が破壊限界

*3 $\quad\left(\sigma_{r} / \sigma g\right) \approx\left(E_{r} / E_{g}\right)$ について

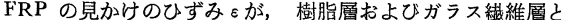

同一てあり，横ひずみの影響を無視すると上記の関係が成立す

る。なお，見かけの縦弹性係数を $E$ とすると

$$
E=\frac{d \sigma}{d \varepsilon}=\left(\frac{d \sigma_{r}}{d \varepsilon}\right)(1-\beta)+\left(\frac{d \sigma g}{d \varepsilon}\right) \beta
$$

$\rho_{r}=f\left(\varepsilon_{r}\right), \sigma g=g(\varepsilon g)$ とおくと

$$
\begin{aligned}
E=\{( & \left.\left(\frac{a f(\varepsilon)}{d \varepsilon}\right)_{0}+\left(\frac{d^{2} f(\varepsilon)}{d \varepsilon^{2}}\right)_{0} \varepsilon+\cdot\right\}(1-\beta) \\
& +\left\{\left(\frac{d g(\varepsilon)}{d \varepsilon}\right)_{0}+\left(\frac{d^{2} g(\varepsilon)}{d \varepsilon^{2}}\right) \varepsilon+\right\} \beta
\end{aligned}
$$

したがって

$$
E=E_{r}(1-\beta)+E_{g} \beta=\left(E_{g}-E_{r}\right) \beta+E_{r}
$$

「材料」第14巻 第139号 


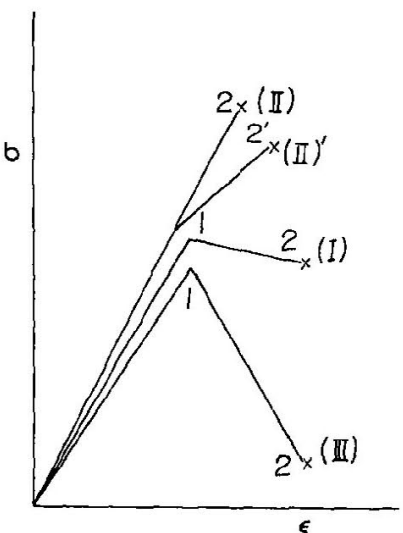

(I) Preceding crack occures at the layer of resin

(I) Grack occures at the same time

(II)' Layer of resin yield

(II) Preceding crack occures at the layer of reinforcement

Fig. 4. Stress-strain relation of FRP.

に達すると，もはや顀荷を分担しなくなると考えたの であるが，実際には樹脂はある程度 (降伏後) ○分担 荷重を受け持ち続けると考えられる。.Shaffer は上記 の模型之同様の考光の下に，䊦脂㬝の降伏を考慮して 次式を得ている。

$$
\begin{aligned}
& \left(\frac{\sigma}{\sigma_{g *}}\right)_{1}=\frac{\sigma_{r s}}{\sigma_{g *}}\left\{1+\beta\left(\frac{E_{g}}{E_{r}}-1\right)\right\} \\
& \left(\frac{\sigma}{\sigma_{q *}}\right)_{2}=\frac{\sigma_{r s}}{\sigma_{g *}}+\beta\left(\frac{\sigma_{g s}}{\sigma_{g *}}-\frac{\sigma_{r s}}{\sigma_{0 *}}\right)
\end{aligned}
$$

ただし， $\sigma_{r s}, \sigma_{g s}$ : 樹脂層，ガラス瀻維層の降伏芯力

以上は，FRP の負荷時の挙動簢単な模型で荐察 しだもので $\sigma_{0 *}, n$ を適当に選定するととによってそ の破壊街重をある程度説明するととができるが，一方， FRP の本質的な破壊の様相を観察すると多くの複雑 な閃題があるととが認められる、Besal と McGarry の研究に上れば初荷重を与えたときの応力一ひずみ曲 線に叔いて“Knee”と呼ばれる部分があり，乙の部分 で群性係数の急激な変化を生ずることが指摘されてい る。その理由として，たとえば朱子織ガラスクロスの ように織維が互に上下在通るように織られている場合 には，引張荷重がかかると繊維がまっすぐになるうと してその周囲の接着部分に高い引張応力とせん断応力 を起とし，ての局部的ひずみがポアソンひずみと結び ついて樹脂がもろいときに破壊を起とし，“Knee”現 象を生ずるものとしている (Fig.5 参照).

しかしながら光学顕微鏡を用いて観察した結果によ れ隹朱子織ガラスクロス，ポリエステル FRP $(\beta=40$ \%) の引張試験において “Knee” 点は $4 \sim 6 \mathrm{~kg} / \mathrm{mm}^{2}$ であるが樹脂部には異常が浔められず, 横繊維内に顕 著なき裂方生じているととが報告されている，Fig.6 は負荷前の断面と $8.3 \mathrm{~kg} / \mathrm{mm}^{2}$ の負荷を与えた後の断

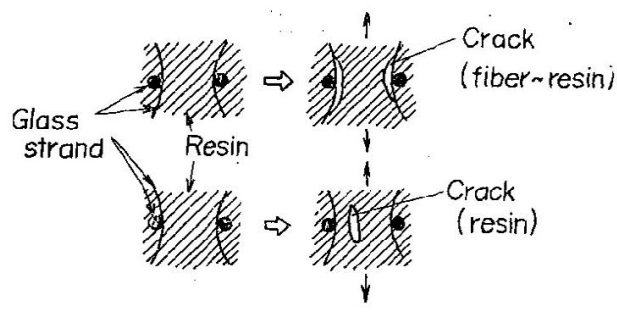

Fig. 5. Model of creation of crack by Besal and McGarry.
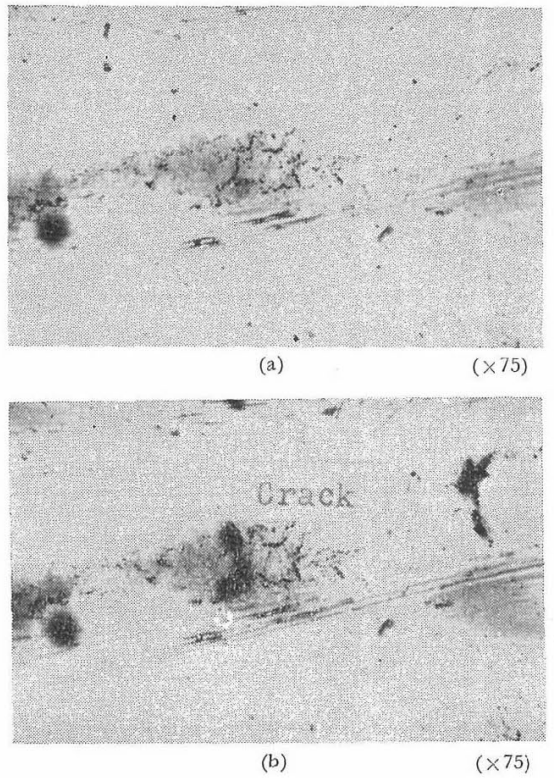

(a) Before loading

(b) After loading

(Cracks observed in the transvers strand of glass $f_{i}$ bers)

Fig. 6. Greation of cracks by loading.

面の比较を示したもので，“Knee”現象を横綫維にお けるき裂生成による剛性変化と考元ると“Knee” 以 前の初期弹性係数 $E_{1}$ と, “Knee" 後の弾性係数 $E_{2} \sigma$ 差 $A E$ は次式となる。

$$
\Delta E=E_{G} \quad E / 2
$$

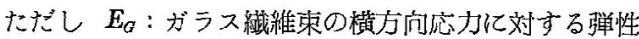
係数

Fig.7 は朱子織ガラスクロス，ポりエステル FRP の $\beta$ と $A E$ の联係を縱軸に $\Delta E$, 横軸に $\beta$ をとって表わし

*4 $\Delta E の$ 式について

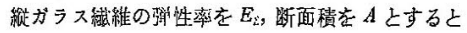

$$
\begin{gathered}
\varepsilon E_{1} A=\varepsilon(1-\beta) A E_{\tau}+\varepsilon_{2}^{\beta} A\left(E_{s}+E_{G}\right) \\
\therefore E_{1}=E_{T}+\frac{\beta}{2}\left(E_{G}+E_{s}-2 E_{r}\right)
\end{gathered}
$$

同棪记

$$
\begin{gathered}
E_{2}=E_{r}+{ }_{2}^{\beta} \cdot\left(E_{s}-2 E_{r}\right) \\
\therefore \Delta E-E_{g}^{\beta}
\end{gathered}
$$




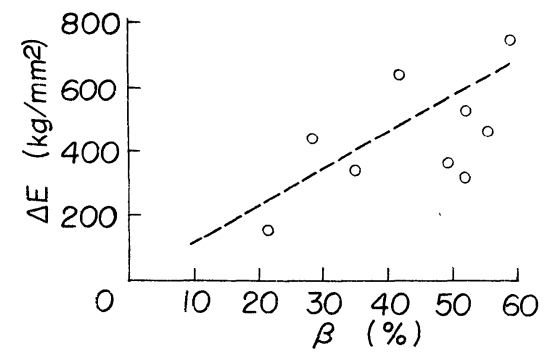

Fig. 7. Variation of elasticity.

た結果で，かなりばらつきが認められるが $\Delta E$ は $\beta$ と ともに増加している，以上は，静的破壊の初期の過程 であるが，負荷の増加とともに樹脂き裂が引き続いて 起とり，縦ガラス縦維の切断とともに破断に至ってい る. Fig.4 に示した “I”の点と上記の “Knee” 点と は同一と考えてよいと思われるが，観察結果が少ない のでなお検討を要するものと思われる.

\section{4 強化プラスチックスの静的強度に 及ぼす他の要因について}

FRP の静的強度がガラス繊維含有率の影響を受け るととを主として述べてきたが，乙のほかにも種々の 要因によって影響を受ける。

\section{1 補強材の種類の影響}

補強材は朱子織ガラスクロスのほかにロービングク ロス，マット等が広く用いられているが，その強度は かなり異なったものとなるＦig.8 はその一例である。

\section{$4 \cdot 2$ 補強材の主方向亡負荷方向の影響}

ガラスクロスを補強材に用いるとその力学的特性は

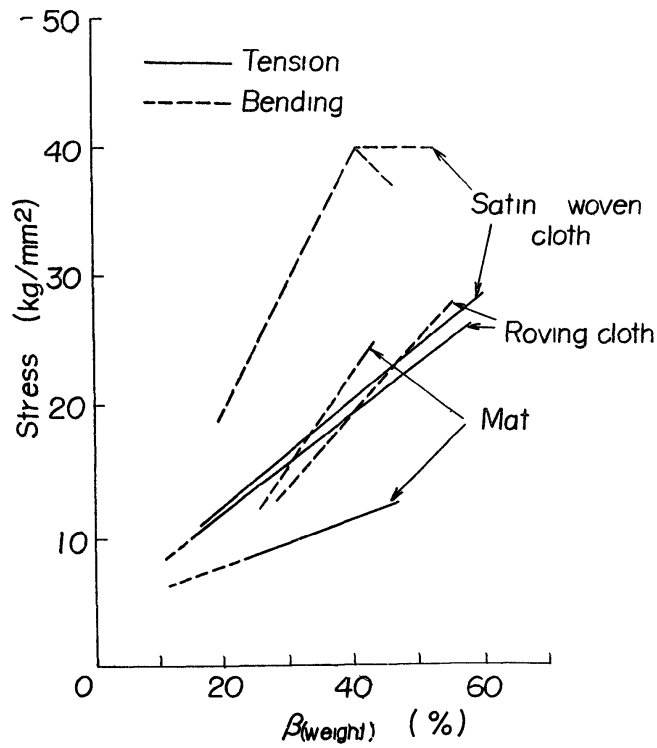

Fig. 8. Effect of the kind of glass fiber construction.

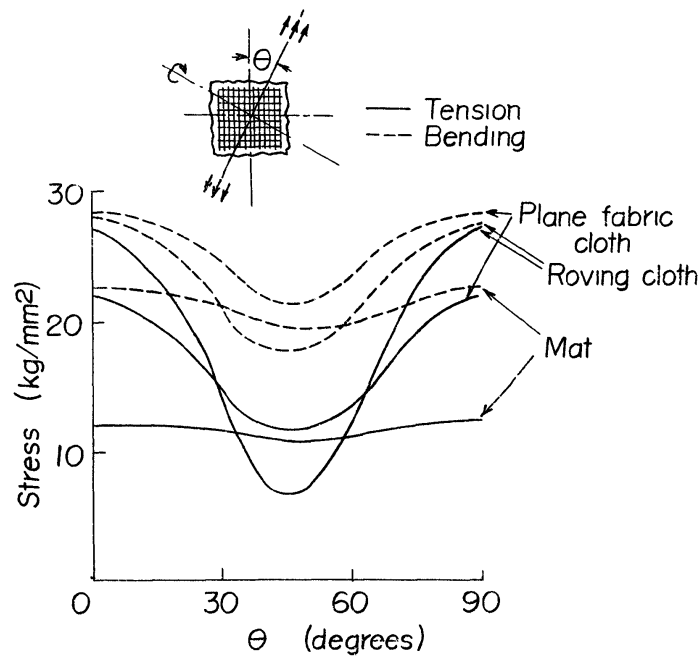

Fig. 9. Effect of unisotropy of glass fiber.

顕著な異方性を示し，強度も負荷の方向によって異な ったものとなる。しかしながら，マットのようなもの を補強材として用いるとほぼ等方性となるＦig.9 は 方向の影響を示した例である。

\section{3 耐候性, 強度の経年変化}

ガラス繊維で強化された FRP は, 而食性, 而候性 がすぐれているとされている。すなわち，高い湿度や 水に触れると表面から拡散現象的に吸湿するが一般に その量はわずかであって，長時間暴露した場合でも 0.5〜 1.0\%以下の重量増加にすぎない．Fig. 10は引張 強度および曲げ強度の経年変化を示した例である。

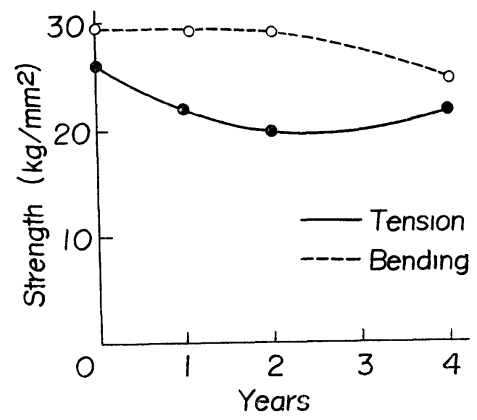

Fig. 10. Effect of exposing period.

\section{4 応力集中による強度低下}

FRP 板に円孔，あるいは切欠きを設けると，その 部分に局部的に応力集中を生ずる．したがって強度低 下を生ずる。乙れは非常に重要な問題であるが，ての 分野に関する研究は比較的少ないようである，Fig.11 は帯板に円孔を設けた場合の結果で，円孔が小さいほ ど強度が増加している。

4.5 その他 


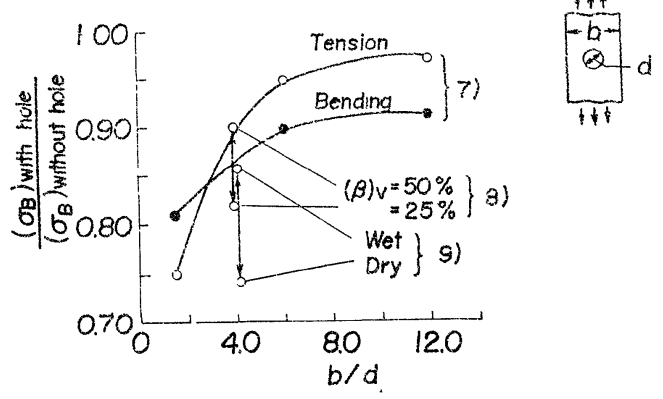

Fig. 11. Effect of stress concentration by a circular hole.
以上の要因以外に重要なものとして温度の影響があ るが，乙れは温度が増加するほど強度が低下するので， アメリカ規格では $160^{\circ} \mathrm{F}$ での曲げ強度は室温で要求さ れる值の $80 \%$ 以上でなければならないとしている，温 度低下は逆に 強度を増加させ， $-150{ }^{\circ} \mathrm{Cぐらいまでそ}$ の傾向があるとされている。

成形条件（アフターキュアーを含めて）の影響，使 用する樹脂の影響等も無視できないが，ててでは割愛 し，最後に試験方法について考えてみよう.

試験規格の制定はアメリカにおいて最も早く行なお れ空軍規格 MIL-R-7575，連邦規格 FS-LP-406b 等が

Table II. Standard of static strength test (FS standard LP-406b, U.S.A.)

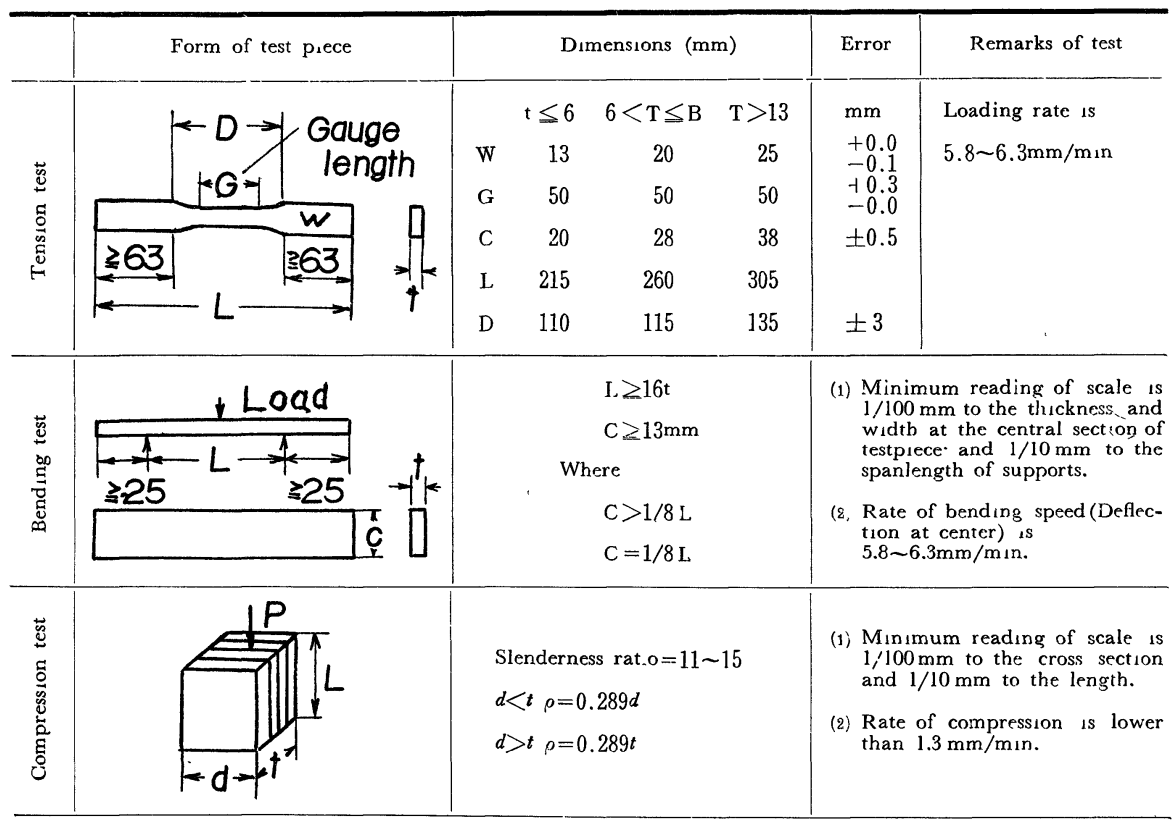

ある. Table II は後者による試験片形状である.

試験の際には気温, 湿度, 荷重速度等に留意しなけ ればならないてとはいうまでもないが，標準状態と湿 潤状態とを規定して試験を行なう場合もある。Fig. 12 はアメリカの艦船用 FRP 規格 MIL-P-17549A に示 されている，静的特性の標準の值である.

\section{5 強化プラスチックスの疲労強度}

強化プラスチックスの疲労強度は静的強度に比べて かなり低い值となる．Fig.13は，朱子織ガラスクロス， ポリエステル FRP の片振引張疲労試験の結果であっ て，ガラス含有率を変えたFig.14亿示すような板状の 試験を用いて実験を行なった結果である、試験速度は

*5 標準状態と湿閏状態について

試験前と試験中の室温は $23 \pm 1^{\circ} \mathrm{C} ， 50 \pm 4 \% \mathrm{R} \mathrm{H}$ 試験前の 温度調整時間は $1 / 8 /$ またはそれ以下の厚みの試料て $48 \mathrm{hr}$ それ 以上の厚みのむのは96hr (FS-I.P-406b, 1952) 湿潤状態は

沸滕水中に $48 \mathrm{hr}$ 浸漬後, 上の標準状態の部屋て試験する.
毎分 1500〜1900で，試験機は，Schenck PHOD 疲 労試験機を用いた，Fig.13からわかるように疲労強度 もガラス繊維含有率 $\beta$ の影響を受け， $\beta$ が大きいほど 強度が大きくなっている．Fig.15は以上の結果に基づ いて縦軸に強度比，横軸に繰返数を取って表わしたも ので，ほほ同一曲線上にあり，静的荷重に対する強度 低下率はほぼ同じ值になっている。

FRP の $S-N$ 曲線は Boller の指摘したように繰返 数Nの増加とともに下にさがり，いわゆる疲労限度は 存在していないようである。しかしガラスクロスを一 定にして，樹脂の性質を変化させて央験を行なった結 果によると $S-N$ 曲線が繰返数の大きいととろでほほ 水平となり，強度もかなりあるととが報告されている。 強化プラスチックスの疲労強度については, 非常に 重要な問題であるので最近多くの研究者によって，実 験研究が行なわれているが，金属材料に比べると，資 料の集積という点でははるかに少ないようである、筆 


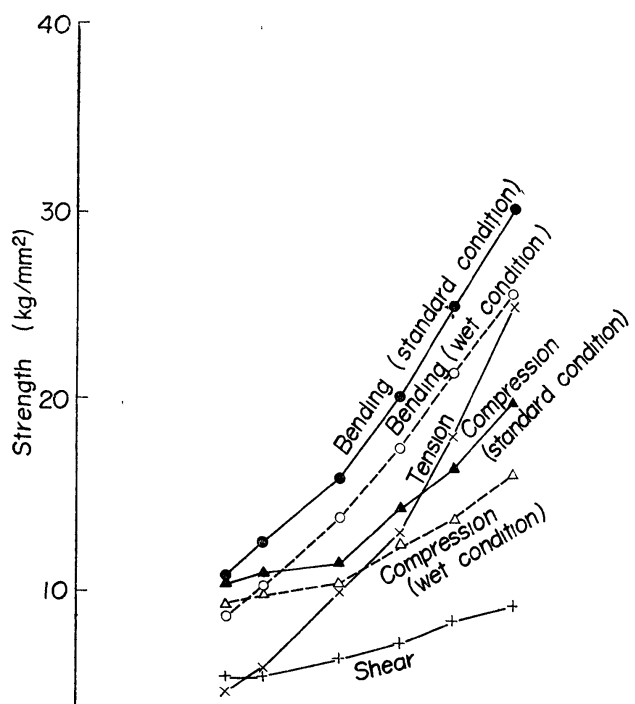

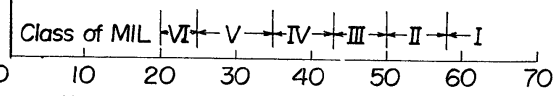
Weight contents of glass fiber (\%)

Fig. 12. Standard of MIL.

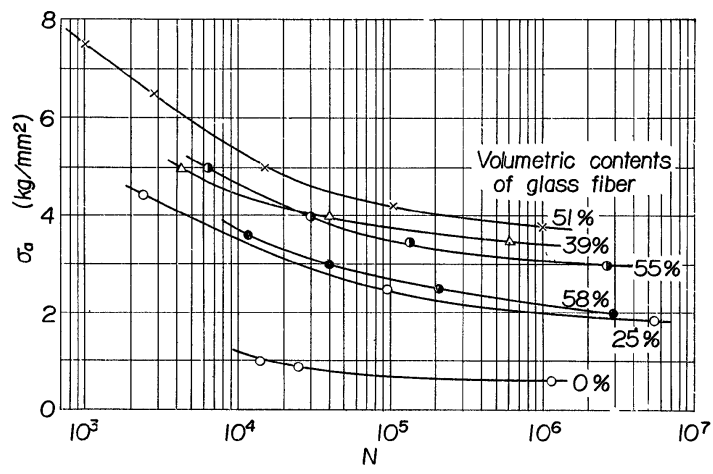

Fig. 13. $S-N$ curve of satin woven glass fiber cloth-polyester FRP under pulsating tensile load.

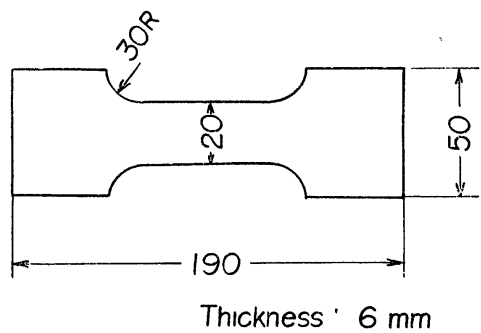

Fig. 14. Form of test piece.

者の数少ない経験から気づいた点をあげてみる.

5 -1 荷重の負荷形式の影響および剛性変化

強化プラスチックス構造物に作用する負荷は単純な 引張り，圧縮でなく曲げが組み合わされたり，せん断

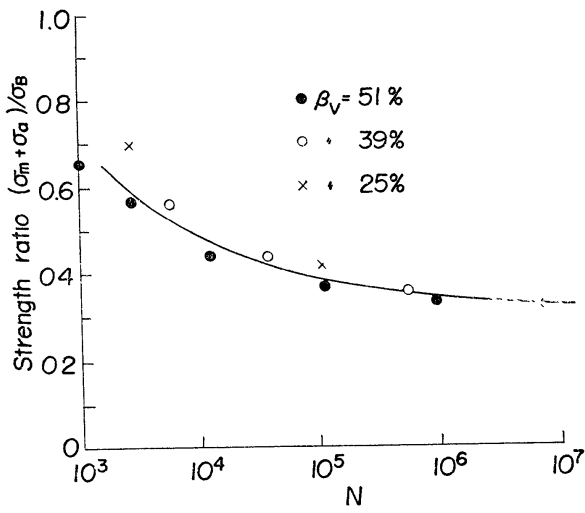

Fig. 15. Lowering of strength by fatigue.

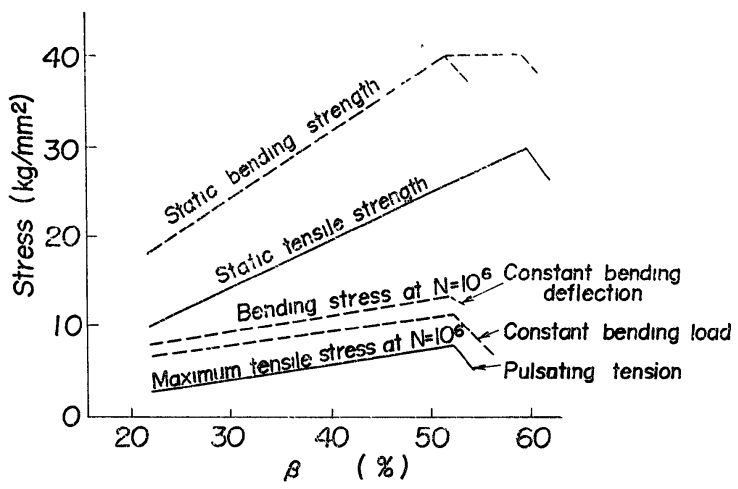

Fig. 16. Effect of glass fiber contents to the fatigue strength of FRP.

が加わったりする場合が多い.したがって繰返引張り と曲げそれぞれに対して疲労強度がどの程度異なるか を知る必要がある。Fig.16は，片振引張りと片持曲げ 試験結果をそれぞれの静的強度に比較した結果で，曲 げの場合，定たわみ試験のほうが定荷重より寿命が長 くなっているが剛性変化の影響によるものと思われる。 実験に用いた材料は朱子織ガラスクロス，ポリエステ ル FRP である，また，剛性変化がかなり大きくなる 場合が多いので剛性低下をある值に規定して疲労強度 とするとともある.

\section{5 -2 荷重繰返速度の影響}

強化プラスチックスの試験方法は大別して繰返引張 りと繰返曲げ（平面曲げ，回転曲げ）の 2 種類である が，繰返速度は統一されておらず “Schenck”試験機 では $1500 〜 3000 \mathrm{cpm}$ ASTM D671-51T では 1720 $\pm 25 \mathrm{cpm}$ “Boldwin” 試験機では $1800 \mathrm{cpm}$ となって いる、試験速度は速いほうが実験効率をよくする点で 望ましいのであるが強化プラスチックスの場合は, か なり粘弾性的特質を有しているので $2000 \mathrm{cpm}$ 以上で 試験すると発熱が著しく結果がよくないようである。

\section{$5 \cdot 3$ 応力集中の影響}


静的強度の項において述べたような強度低下が疲学 の場合にも著しい. 円孔試験片の強度低下は平滑試験 片の $82 \%(\beta=50 \%) \sim 79 \%(\beta=25 \%)$ である.

\section{5 - 4 変動荷重の影響}

Minner の仮設があてはまらず，積算繰返数比は一 般に 1 以下である.

\section{$\mathbf{5}$-5 温度の影響}

温度が上昇すると疲労強度は減じ，逆に低温では強 度が増加しており，静的強度と同様の傾を示している。

\section{$5 \cdot 6$ 成形条件の影響}

成形の際の真空脱泡の影響, アフターキュアーの影 響等であるが，片持曲げ試験によって求めた前者の影 響をFig. 17亿示す。

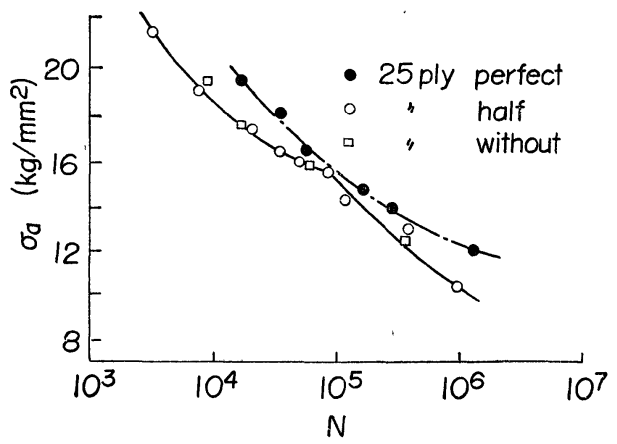

Fig. 17. The effect of removal of bubble by vacuum pump.

以上のほか, 補強材の異方性の影響, 平均応力の影 響, 運転休止の影響等も報告されている。

なお，疲労破壊の機構については光学顕微鏡による 観察結果もあるが, 今後の研究に待つ点が多いように 思われる。

以上, 静的強度, 疲労強度を中心に述べたのである が，強度特性の他の項目として衝撃強度，ほふく強度， 等についても多くの研究が行なわれている.

\section{6 む す び}

強化プラスチックスの強度に関して, 主としてガラ ス繊維クロスを補強材として用いた場合について考察 したのであるが充分に意を尽くすてとができなかった。 金属材料と比較するとかなり異なった性質を有してお
り，長短相半ばしているように思われるが，その長所 を生かして利用すれば，非常にすぐれれ材料として役 だちうるものと思われる。

(昭和39年10月 3 日 第13回レオロジー討論会にて講演)

\section{参考文 献}

1）林毅，旭ファイバーグラス研究資料，p.16(1960).

2) Shaffer, B.W., Stress Strain Relations of Reinforced Plastics. J. AIAA, 2, 348 (1964).

3) Besal, M.B., and F.J. McGarry, Failure Mechanisms in Glass Fiber Reinforced Plastics, ASTM Bulletin (TP 156) (1959).

4) 藤井太一, 増田雄市郎, 第 5 回構造の軽量化シン ポジウム前刷, 187 (1964).

5) 田部井清, 強化プラスチックス, 8, 184 (1962).

6) 旭ファイバーグラス，FRP 資料-1，p.20 (1961).

7) Strauss, E.L., Plastic Technology, 8, 35 (1958).

8) 藤井太一, 築添正, 大㭇茂寿, 第 3 回構造の軽量 化シンポジム前刷 (1962).

9) MHBK-17, Plastics for flight vehicles, I, Reinforced Plastics, 29 (1959).

10) Boller, K.H., Fatigue Properties of fibrous glass reinforced plastics laminates subjected to various conditions, Modern Plastics, p. 163 (1957).

11）仁木正夫，FRP の疲れ強さに及ぽす樹脂の影響 (1965) 強化プラスチックス研究会

12）藤井太一, 強化プラスチックスの工業的利用とそ の設計に関する講習会前刷, 143 (1953).

13）藤井太一，大槻茂寿，水川清，増田雄市郎，第 5 回構造の軽量化シンポジム前刷, 179 (1964).

14）遠藤吉郎, 強化プラスチックスの疲れ強さに及ぼ 至温度の影響, (19064) 強化プラスチックス研究会

15）島村弨次，強化プラスチックス，5，302 (1952).

16）大槻茂寿, 多田弘, 強化プラスチックスの疲れ強 さに及ぼす成型条件の影響, (1954) 強化プラスチ ックス研究会

17）藤谷景三, 強化プラスチックスの疲れ強さに及ぽ す運転休止の影響, (1964) 強化プラスチックス研 究会 